\section{Socioeconomic inequalities and exposure to traffic-related air pollution in the city of São Paulo, Brazil}

\author{
Desigualdades socioeconômicas e exposição aos \\ poluentes gerados pelo tráfego veicular em \\ São Paulo, Brasil
}

\author{
Desigualdades socioeconómicas y exposición a \\ los contaminantes generados por el tráfico de \\ vehículos en São Paulo, Brasil
}

\begin{abstract}
Air pollution is a leading public health concern. In addition, poor populations have been reported as showing increased exposure to such pollution. The current study thus aimed to evaluate the socioeconomic status of the population exposed to vehicle-related air pollution in the city of São Paulo, Brazil. The study used data from the 2010 Census on head-of-household's mean monthly income and the percentage of households connected to the sewage system. Exposure to air pollutants was estimated according to traffic density in the census tract plus a $200 \mathrm{~m}$ surrounding buffer. The relationship between exposure and socioeconomic variables was analyzed by the Kruskal-Wallis test. Exposure increased with increasing socioeconomic status $(p<0.001)$. The population with the highest socioeconomic status lives in the most polluted areas of the city. However, place of residence alone is not capable of measuring exposure. The study suggests that future epidemiological studies include other indicators of vulnerability.
\end{abstract}

Environmental Risks; Air Pollution; Vehicle Emissions; Social Vulnerability; Environmental Health

\author{
Mateus Habermann 1 \\ Miriam Souza 1 \\ Rogério Prado 1 \\ Nelson Gouveia 1
}

\section{Resumo}

A poluição atmosférica é uma das maiores preocupações para a saúde pública. Além disso, populações pobres têm sido relatadas como mais expostas a essa poluição. Desse modo, este estudo teve por objetivo avaliar a situação socioeconômica da população exposta aos poluentes atmosféricos gerados por fluxo veicular no $\mathrm{Mu}$ nicípio de São Paulo, Brasil. Foram utilizadas informações da renda média mensal do chefe de domicílio e percentual de domicílios ligados à rede geral de esgoto, dos setores censitários do Censo Demográfico 2010. A exposição aos poluentes foi estimada pela densidade de tráfego do setor censitário e uma faixa adicional de $200 \mathrm{~m}$. A relação entre a exposição e variáveis socioeconômicas foi analisada pelo teste KruskalWallis. A exposição aumentou conforme a melhora da situação socioeconômica $(p<0,001)$. A população de melhor nível socioeconômico reside em áreas mais poluídas. Entretanto, o local de residência, apenas, não é capaz de indicar maior exposição. Sugere-se a inclusão de outros indicadores de vulnerabilidade em futuros estudos epidemiológicos.

Riscos Ambientais; Poluição do Ar; Emissões de Veículos; Vulnerabilidade Social; Saúde Ambiental 


\section{Introduction}

Various epidemiological studies have found an association between exposure to air pollutants and adverse health effects, including an increase in hospitalizations, increased mortality, decreased life expectancy, etc. 1 .

Growing economic development and urbanization in developing countries have been accompanied by a rapid increase in the number of motor vehicles, the main contributors to air pollution in large cities. In São Paulo, Brazil, motor vehicle traffic accounts for $97.4 \%$ of CO emissions, $77.1 \%$ of hydrocarbons, $81.7 \%$ of nitrogen oxides $\left(\mathrm{NO}_{\mathrm{x}}\right)$, and $40 \%$ of inhalable particulate matter $\left(\mathrm{PM}_{10}\right)^{2}$.

Various authors analyzing the interface between environmental and legal issues have suggested that persons in adverse socioeconomic position are more exposed to air pollution $3,4,5$ and that this inequality acts as a driver for lower health levels among the poor, either because they are more exposed or because they suffer from other forms of deprivation and thus become more susceptible to the harmful effects of air pollutants 5 .

The current study thus aimed to evaluate the socioeconomic position of the population exposed to air pollution from motor vehicle traffic in the city of São Paulo, to verify the occurrence of inequalities in this exposure.

\section{Methods}

Data from 2007 on the road system, such as traffic counts and simulation on the main streets and roads (thoroughfares, cross streets, and rapid transit) were provided by the São Paulo Municipal Traffic Engineering Company (CET), including tables, the street grid, and the number of vehicles per hour. For stretches that lacked traffic statistics $(5.8 \%$ of the total), the study assigned a mean value based on the respective street's overall classification.

Local street traffic was estimated by the CET in 926 regions demarcated by the public traffic and transportation planning department (origin-destination zones). The sum of traffic in each of these regions was divided by the total length of all the local streets contained in them. The traffic density (TDi) (vehicles per meter of local streets) was then obtained for each region $(i)$. This measure was then multiplied by the length of local street segments (LSS), in meters, contained in the respective regions, thus obtaining the traffic for each local street segment $(T)$.
$T=\left(\frac{\sum_{i} \text { traffic }}{\sum_{i} \text { length }}\right) \times$ LSS

An indirect indicator of exposure to pollutants generated by motor vehicle traffic was constructed for each census tract using Mapinfo, professional version 8.5 (MapInfo Corp., New York, USA). Since the census tracts vary considerably in size, many of them represent only one block or building each, and therefore do not contain any stretch of street and could have a null traffic value. This question was solved using the same approach as Gunier et al. 4 and Reynolds et al. 6 , where the limits of each tract were extended with a 200-meter surrounding buffer. This $200 \mathrm{~m}$ distance also represents the dispersal of air pollutants from a street 4,6,7. Traffic density consists of multiplying the vehicle volume by the length of the street segments, followed by dividing by the area of the census tract (with the 200-meter buffer).

$T D I=\frac{\sum_{i}(A M D T \times L)}{A_{i}}$

Where $T D i$ is the traffic density in each census tract $+200(i)$, AMDT is the annual mean daily traffic (vehicles/hour - VPH), $L$ is the length of the street segment $(\mathrm{km})$, and $A$ is the area of the census tract (in $\mathrm{km}^{2}$ ) with the 200-meter buffer. The unit is expressed as $\mathrm{VPH} / \mathrm{km}^{2}$. For the purposes of this study, census tracts +200 meters are referred to generically as tracts. A sensitivity analysis of the model was also conducted using different buffers around the census tracts $(50 \mathrm{~m}$, $100 \mathrm{~m}$, and $150 \mathrm{~m}$ ).

The socioeconomic analysis used data from the 2010 Population Census conducted by the Brazilian Institute of Geography and Statistics (IBGE. http://www.ibge.gov.br), contained in the census tract database, with information on the number of permanent private households, number of private households connected to the sewage system, heads of households 10 years or older, and mean monthly nominal income. The study's socioeconomic indicators included the mean income of heads-of-households in each census tract and the percentage of households connected to the sewage system in each tract.

Mean income by census tract was stratified as $\leq 2,2-3,03-5,5-10,10-20$, and $>20$ times the monthly minimum wage (which was BR\$ 510.00 or US\$205.00 at the time of the 2010 Census). Connection to the sewage system was classified in quartiles and annual mean daily traffic as a continuous variable. Differences between socioeconomic groups and exposure to air pollution in the tracts was analyzed with the Kruskal-Wallis non-parametric test $(\alpha=5 \%)$ 


\section{Results}

The city of São Paulo had nearly 19,000 census tracts in the 2010 Census. As shown in Table 1 , more than $60 \%$ of the tracts present a mean income of twice the minimum wage or less, indicating a non-parametric income distribution between them.

Mean traffic increased gradually with income in the census tract. However, maximum pollution exposure occurred in the group with 2-3 times the minimum wage.

Figure 1 shows the boxplots for traffic between the income groups. Median traffic in the group with income up to twice the minimum wage was lower than in the other income groups, and the $75^{\text {th }}$ percentile (upper part of the box) was lower than the median for the other groups. The group with income $>20$ times the minimum wage showed the highest median and $75^{\text {th }}$ percentile. However, median traffic did not show the same trend as mean traffic (Table 1), while similar values were observed between the income groups earning 5-10 and 10-20 times the minimum wage.

Analysis of sewage system coverage assumed that lower coverage corresponded to lower socioeconomic status in the census tract. Table 2 shows that in $47 \%$ of the census tracts, $100 \%$ of households were connected to the sewage system. Connection to the sewage system showed a similar trend to that of income. The group of tracts with lower coverage also had the highest proportion with low mean traffic density (43.5\%), while the group of tracts with $100 \%$ of households connected to the sewage system showed the highest percentage of high air pollution exposure (56.9\%).

The Kruskal-Wallis test identified statistically significant differences between traffic density, quartiles of coverage by the sewage system, and income $(\mathrm{p}<0.001)$. Sensitivity analysis using different buffers around the tracts showed similar results to those in the model based on a 200-meter buffer (data not shown).

\section{Discussion}

According to this study, the population with the highest socioeconomic status lives in areas with heavier vehicle traffic and thus with more air pollution, when compared to the poorer population.

This result is the opposite of that in other places where people with low socioeconomic status live in the areas with heavier air pollution $3,4,8,9,10,11$.

This phenomenon results from the way the city of São Paulo was occupied, since the down- town area and its immediate vicinity, with the heaviest vehicle traffic, concentrate a large share of the urban infrastructure for commerce, leisure, and workplaces, tending to have higher real estate values and residents with higher purchasing power. The real estate located on the city's periphery is generally less valuable and is occupied by the underprivileged population.

Although the literature generally indicates higher exposure to air pollution in the poor population, this evidence is mainly limited to Europe, with some studies suggesting that the opposite association can occur 9,12,13.

Aguilera et al. 12 identified higher levels of $\mathrm{NO}_{2}$ and benzene, toluene, ethyl-benzene, and xylenes (BTEX) among women with university degrees, when compared to those with secondary or primary schooling. Differences in the structure and spatial distribution of social classes between European and North American cities could explain these discrepancies.

According to Forastiere et al. 13, socioeconomic status in Rome showed a gradual association with air pollution (vehicle traffic, PM, CO, $\mathrm{NO}_{\mathrm{x}}$, and benzene), indicating that the upper income population lives in more polluted areas, precisely because it is concentrated in the central area of the city. According to Hoek et al. ${ }^{9}$, individuals in the Netherlands living close to the main roadways have more schooling and work less at manual jobs.

Although in this study the wealthier lived in the most polluted areas, it does not necessarily mean greater exposure to negative health impacts. Importantly, these areas have more new vehicles with lower emission factors when compared to the periphery, where the older vehicles circulate along with trucks, prohibited from circulating in the city center.

The poorer population may remain longer hours of the day on the roads and streets, close to traffic, commuting to work in public transportation, or working in outdoor environments 14 . Theoretically, persons with worse socioeconomic position are also more susceptible to the effects of air pollution, since they have less or no access to information or resources to purchase healthy foods, resulting in reduced intake of antioxidant vitamins that could otherwise protect them from the adverse consequences of exposure to air pollution, besides having limited access to medical care and receiving inadequate prescriptions for respiratory conditions such as asthma. Psychosocial stress and violence may also be greater among the poor, further increasing their susceptibility to illnesses 5 . In addition, smoking tends to be more prevalent among lowincome individuals 15 . 
Table 1

Descriptive statistics on traffic density in census tracts classified by mean income.

\begin{tabular}{lcccc}
\hline \multirow{2}{*}{ Times minimum wage } & \multicolumn{4}{c}{ Traffic density } \\
& $\mathbf{n}(\%)$ & Mean $(\mathrm{SD})$ & Median & Maximum \\
\hline$\leq 2$ & $11,772(62.1)$ & $3,983.7( \pm 15,284.3)$ & 987.4 & 714.273 .3 \\
$>2-3$ & $2,344(12.4)$ & $10,666.3( \pm 32,805.3)$ & $4,388.6$ & $1,043,190.1$ \\
$>3-5$ & $1,592(8.4)$ & $11,709.8( \pm 24,180.5)$ & $5,206.5$ & $475,683.0$ \\
$>5-10$ & $2,601(13.7)$ & $12,353.5( \pm 24,104.9)$ & $5,973.4$ & $505,543.0$ \\
$>10-20$ & $613(3.2)$ & $11,271.0( \pm 16,544.0)$ & $5,691.6$ & $152,230.5$ \\
$>20$ & $31(0.2)$ & $16,449.1( \pm 24,000.8)$ & $7,481.4$ & $106,198.4$ \\
Total & $18,953(100.0)$ & $6,863.9( \pm 20,748.9)$ & $2,157.4$ & $1,043,190.1$ \\
\hline
\end{tabular}

SD: standard deviation.

Figure 1

Boxplot of traffic density between income groups, by census tract, in the city of São Paulo, Brazil, 2010.

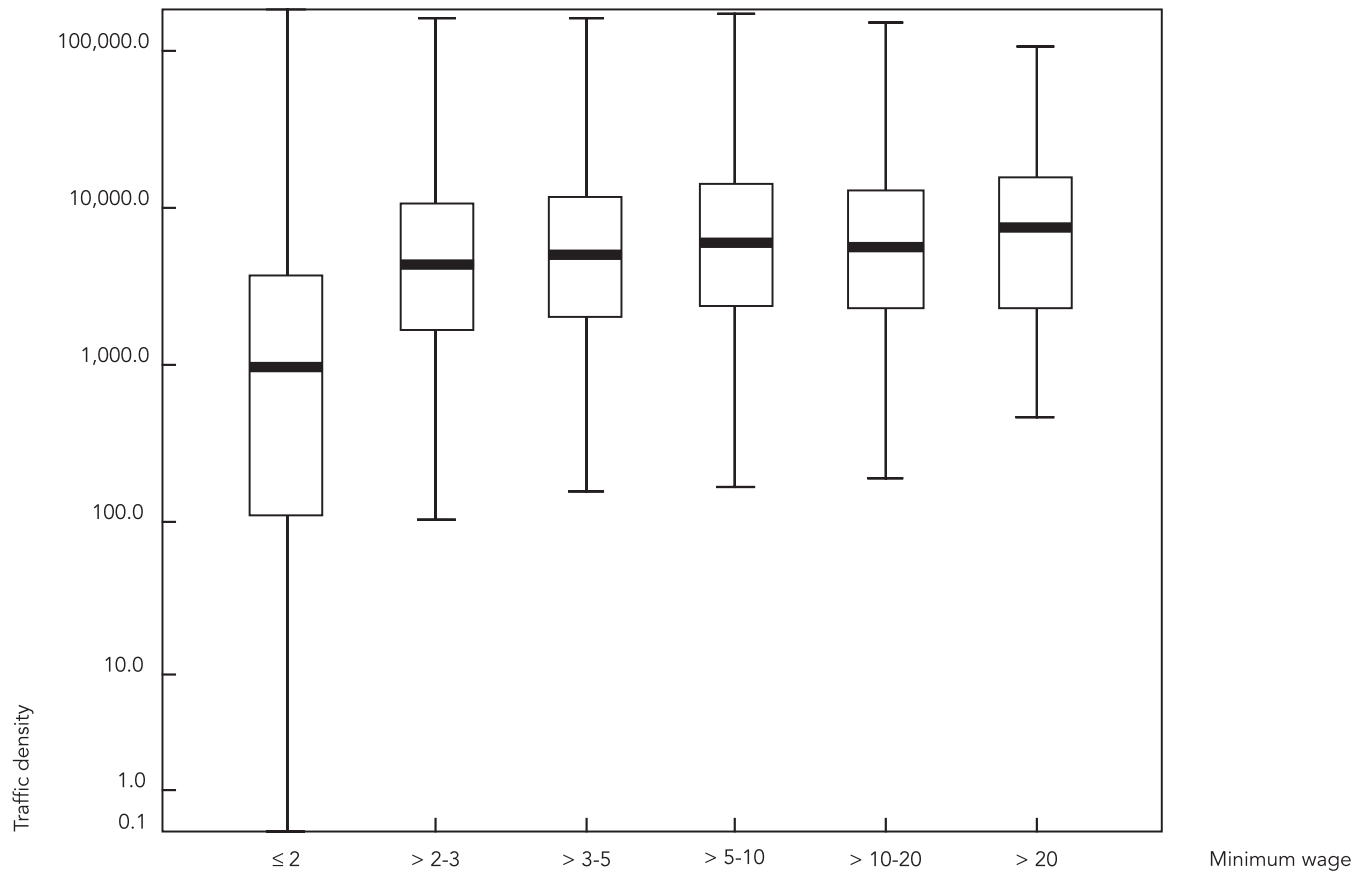

As reported in other studies 4,6,7, the method adopted to assess exposure has limitations for inferring individual exposure, since information such as period of residence, time spent at home, commuting from home to work or school, and the location of the workplace or school are not available for spatial clusters (census tracts).
The vehicle traffic data are from 2007 and the socioeconomic data from the 2010 Census. The traffic counts and simulations are conducted by the CET in ten-year periods, and the most current and complete data are from 2007. However, we believe that during this three-year gap between the two data sources, no significant 
Distribution of percentage of households connected to sewage system in quartiles of census tract traffic density in the city of São Paulo, Brazil, 2010.

\begin{tabular}{lccccc}
\hline Sewage (\%) & & \multicolumn{2}{c}{ Traffic density } & Total \\
& 1st quartile (\%) & 2nd quartile (\%) & 3rd quartile (\%) & 4th quartile (\%) \\
\hline 295.4 & $2,060(43.5)$ & $1,250(26.4)$ & $848(17.9)$ & $588(12.4)$ & $4.746(25.0)$ \\
$95.4--\mid 99.6$ & $1,041(22.0)$ & $1,323(27.9)$ & $1,218(25.7)$ & $1,147(24.2)$ & $4.729(25.0)$ \\
$99.6--\mid 100$ & $103(2.2)$ & $142(3.0)$ & $157(3.3)$ & $165(3.5)$ & $567(3.0)$ \\
100 & $1,534(32.4)$ & $2,024(42.7)$ & $2,515(53.1)$ & $2,838(56.9)$ & $8,911(47.0)$ \\
\hline
\end{tabular}

changes occurred in the traffic's distribution, and a probable overall increase in vehicle traffic during this same period must have occurred homogeneously across the city.

The assignment of mean values to the streets that lacked directly observed traffic values could potentially pose a limitation, but these street segments represented only $5.8 \%$ of the total. We believe that the mean traffic estimate for these segments did not alter the overall study results.

Some factors such as mean age of the vehicle fleet, type of fleet (light versus heavy), or meteorological variables such as wind direction were not considered in calculating traffic density in this study. However, the traffic data for local streets (cross streets) were included, unlike the study by Gunier et al. 4, which identified the lack of this data as a limitation.
Despite the above-mentioned limitations, it was important to use street traffic information to construct indirect measures to evaluate exposure to air pollution. These measures can be especially useful in locations that lack air quality monitoring networks to investigate the possible negative impacts of vehicle traffic on the population's health.

The fact that socioeconomic variables are related to annual mean daily traffic and air pollution emphasizes the importance of controlling for them in epidemiological studies. If poor people are less exposed to air pollution, information on vulnerabilities other than low income should be included (such as violence, diet, and access to health care) in order to rule out potentially erroneous associations between exposure to air pollutants and the outcome variable. 


\section{Resumen}

La contaminación del aire es una preocupación importante para la salud pública. Por otra parte, los pobres han sido identificados como los más expuestos a contaminación. Así, este estudio tuvo como objetivo evaluar la situación socioeconómica de la población expuesta a contaminantes del aire generado por el tráfico de vehículos en São Paulo, Brasil. La información de la renta media mensual del jefe de familia y el porcentaje de hogares conectados a la red de alcantarillado público se obtuvo de los sectores censales 2010. La exposición a los contaminantes se estimó por la densidad de tráfico de sectores censales y una banda adicional de 200m. La relación entre la exposición y las variables socioeconómicas se analizó mediante la prueba de Kruskal-Wallis. La exposición aumenta con la mejora de la situación socioeconómica $(p<0,001)$. La población de mayor estatus socioeconómico vive en zonas más contaminadas. No obstante, el lugar de residencia, solamente, no es capaz de indicar una mayor exposición. Se sugiere la inclusión de otros indicadores de vulnerabilidad en los futuros estudios.

Riesgos Ambientales; Contaminación del Aire; Emisiones de Vehículos; Vulnerabilidad Social; Salud Ambiental

\section{Contributors}

M. Habermann contributed to writing the article and relevant critical revision of the intellectual content. $\mathrm{M}$. Souza and R. Prado collaborated in the data analysis and interpretation. N. Gouveia contributed to the final approval of the version for publication.

\section{References}

1. World Health Organization. WHO air quality guidelines: global update 2005. Report on a working group meeting. Geneva: World Health Organization; 2006.

2. Companhia Ambiental do Estado de São Paulo. Qualidade do ar no estado de São Paulo 2011. São Paulo: Companhia Ambiental do Estado de São Paulo; 2012.

3. Dolinoy DC, Miranda ML. GIS modeling of air toxics releases from tri-reporting and non-tri-reporting facilities: impacts for environmental justice. Environ Health Perspect 2004; 112:1717-24.

4. Gunier RB, Hertz A, Von-Behren J, Reynolds P. Traffic density in California: socioeconomic and ethnic differences among potentially exposed children. J Expo Anal Environ Epidemiol 2003; 13:240-6.

5. O'Neill MS, Jerrett M, Kawachi I, Levy JI, Cohen AJ, Gouveia N, et al. Health, wealth, and air pollution: advancing theory and methods. Environ Health Perspect 2003; 111:1861-70.
6. Reynolds P, Behren JV, Gunier RB, Goldberg DE, Hertz A, Smith D. Traffic patterns and childhood cancer incidence rates in California, United States. Cancer Causes Control 2002; 13:665-73.

7. Chacraborty J, Schweitzer LA, Forkenbrock DJ. Using GIS to assess the Environmental Justice consequences of transportation system changes. Transactions GIS 1999; 3:239-58.

8. Apelberg BJ, Buckley TJ, White RH. Socioeconomic and racial disparities in cancer risk from air toxics in Maryland. Environ Health Perspect 2005; 113:693-9.

9. Hoek G, Brunekreef B, Goldbohm S, Fischer P, van den Brandt PA. Association between mortality and indicators of traffic-related air pollution in the Netherlands: a cohort study. Lancet 2002; 360:1203-9. 
10. Kingham S, Pearce J, Zawar-Reza P. Driven to injustice? Environmental Justice and vehicle pollution in Christchurch, New Zealand. Transportation Research Part D 2007; 12:254-63.

11. Pearce J, Kingham S. Environmental inequalities in New Zealand: a national study of air pollution and environmental justice. Geoforum 2008; 39:980-93.

12. Aguilera I, Guxens M, Garcia-Esteban R, Corbella T, Nieuwenhuijsen MJ, Foradada CM, et al. Association between GIS-based exposure to urban air pollution during pregnancy and birth weight in the INMA Sabadell Cohort. Environ Health Perspect 2009; 117:1322-7.

13. Forastiere F, Stafoggia M, Tasco C, Picciotto S, Agabiti N, Cesaroni G, et al. Socioeconomic status, particulate air pollution, and daily mortality: differential exposure or differential susceptibility. Am J Ind Med 2007; 50:208-16.
14. Graneski S, Bolin B, Boone C. Criteria air pollution and marginalized populations: environmental inequity in Metropolitan Phoenix, Arizona. Soc Sci Q 2007; 88:535-54.

15. Silva GA, Valente JG, Almeida LM, Moura EC, Malta DC. Tobacco smoking and level of education in Brazil, 2006. Rev Saúde Pública 2009; 43:48-56.

Submitted on 27/Nov/2012

Final version resubmitted on 16/Jul/2013

Approved on 29/Jul/2013 